\title{
In vitro assessment of deworming potential of Guiera senegalensis in Nigerian ethnoveterinary industry using Caenorhabditis elegans
}

\author{
Haladu Ali Gagman 1,2, Hamdan Ahmad', Nik Ahmad Irwan Izzaudin Nik Him ${ }^{1}$ and Silas Wintuma Avicor ${ }^{3^{*}}$ (D)
}

\begin{abstract}
Background: Although Guiera senegalensis is used as a dewormer in ethnoveterinary health care in Nigeria, its anthelmintic potential has not been validated. Hence, this work investigated the in vitro anthelmintic potential of $G$. senegalensis extracts on two Caenorhabditis elegans strains: Bristol N2 (wild type/ivermectin susceptible) and DA1316 (ivermectin resistant).

Results: Aqueous and methanol extracts of $G$. senegalensis were tested against the motility of the L4 larvae at two exposure periods of 24 and $48 \mathrm{~h}$ and found to be active against the C. elegans strains. Motility of C. elegans DA1316 was reduced to $18.6 \%$ and $8.3 \%$ by aqueous and methanol extracts, respectively, at $2.0 \mathrm{mg} / \mathrm{ml}$ after $48 \mathrm{~h}$, whereas that of C. elegans DA1316 treated with ivermectin $(0.02 \mu \mathrm{g} / \mathrm{ml})$ remained above $95 \%$. The motility of C. elegans Bristol N2 was reduced to $16.6 \%$ and $7.2 \%$ by aqueous and methanol extracts, respectively, at $2.0 \mathrm{mg} / \mathrm{ml}$ after $48 \mathrm{~h}$ and $\leq 2.7 \%$ by ivermectin $(0.02 \mu \mathrm{g} / \mathrm{ml})$. Activity of the plant extracts was concentration and time dependent.

Conclusions: This work confirms the anthelmintic activity of $G$. senegalensis and its effectiveness against ivermectinresistant nematodes, thus validating its ethnoveterinary use as an animal dewormer in Nigeria and pharmacological potential as a source of anthelmintic compounds against ivermectin-resistant nematodes. There is, however, the need for in vivo studies to confirm the in vitro efficacy of the extracts.
\end{abstract}

Keywords: Anthelmintic, Caenorhabditis elegans, Ethnoveterinary, Guiera senegalensis, Larval motility, Nigeria

\section{Background}

Gastrointestinal parasitic nematode infection is one of the global pathological problems with severe consequences for small ruminant production (Zajac and Garza 2020; Arsenopoulos et al. 2021). The pathological effects of this infection on animal health include low intake of food, anaemia, impairment of digestion, poor absorption of nutrients, weight lost and diarrhoea (Hoste 2001). Chemotherapeutic agents are commonly

\footnotetext{
*Correspondence: wintuma@live.com

${ }^{3}$ Entomology Division, Cocoa Research Institute of Ghana, New Tafo-Akim, Eastern Region, Ghana

Full list of author information is available at the end of the article
}

used for the management of the parasites (Zajac and Garza 2020; Arsenopoulos et al. 2021). However, in several parts of the world, the parasites have developed resistance to synthetic drugs such as ivermectin and several others (Jackson et al. 2012; Arsenopoulos et al. 2021). For instance, Herrera-Manzanilla et al. (2017) reported of benzimidazole, levamisole and ivermectin resistance in gastrointestinal nematodes of sheep in Mexico. Resistance to anthelmintics has also been reported in livestock in India (Singh et al. 2017), the Netherlands (Ploeger and Everts 2018) and South Africa (Mphahlele et al. 2021). The development of resistance to modern chemotherapy, side effects of the 
drugs in treated animals, residual effects of anthelmintics in the environment and food as well as the cost of these commercial anthelmintics call for natural anthelmintics from plants as an alternative to synthetic drugs (Mazhangara et al. 2020). The search for natural anthelmintics involves in vitro screening of plants or plant products as the first line of action to determine their efficacy. In vitro screening of plants for anthelmintics faces several challenges such as high cost, time-consuming procedures, ethical constraints and difficulty in obtaining adult stage nematodes for efficacy evaluation. These challenges have been addressed to a minimum with the discovery of Caenorhabditis elegans and its subsequent uses as a laboratory model in evaluating anthelmintics (Katiki et al. 2011; Hahnel et al. 2021; Taki et al. 2021).

Sustainable control of worms has been threatened by the emergence of resistant parasitic species especially those of small ruminants because understanding the genetic basis of resistance in parasitic nematodes is extremely difficult. However, with its emergence as a research model, $C$. elegans has been central to defining the mechanism of action of drugs and serves as a model for understanding and managing anthelmintic resistance (Holden-Dye and Walker 2014). Although the extent of reproducing the effect of anthelmintics on C. elegans on other nematodes is variable (Keiser 2015), it is useful for identifying potential anthelmintics (Holden-Dye and Walker 2014; Burns et al. 2015; Taki et al. 2021).

Traditionally, herbal practitioners especially from socio-economically disadvantaged countries within the tropical and subtropical regions have been relying on natural products from plants for the treatment of a wide range of infections including helminth parasites owing to their low cost, easy accessibility and little or absence of side effects (Yadav and Singh 2011; Mazhangara et al. 2020). Despite the long history of the application of traditional herbal medicine in the treatment of diverse ailments, there is scarcity of proper documentation and validation of its use (Mazhangara et al. 2020).

Guiera senegalensis (Myrtales: Combretaceae), a small tropical shrub, is used for human and veterinary health purposes in Africa (Adamu et al. 2005; Ademola 2016; Alshafei et al. 2016; Dirar and Devkota 2021). Although there is extensive utility of this plant in Nigerian ethnoveterinary industry as a dewormer by small ruminant breeders, its anthelmintic potential has not been validated. This study assessed the efficacy of extracts of $G$. senegalensis against the motility of larvae of $C$. elegans strains with contrasting ivermectin-resistance status to validate the ethnoveterinary use of the plant.

\section{Methods}

\section{Plant material and extraction}

Bark of G. senegalensis stem was collected from Azare in Bauchi State, Nigeria in December 2016 and authenticated (Voucher specimen No. 900103) and deposited as described in Gagman et al. (2018). The bark was peeled with a sterile blade, washed with distilled water, crushed into smaller fragments and shade-dried for 3 weeks before being pulverized into powder. Phytochemical extraction was carried out by maceration using distilled water and $80 \%$ methanol as solvents for the aqueous and methanol extracts, respectively (Lienou et al. 2015) at the School of Biological Sciences, Universiti Sains Malaysia. Briefly, distilled water $(250 \mathrm{ml})$ was added to the powdered sample $(50 \mathrm{~g})$ and stored at room temperature $\left(27.5 \pm 2.5^{\circ} \mathrm{C}\right)$ for 5 days. The infusion was filtered through a Whatman No. 1 filter paper. The filtrate was concentrated by drying at a temperature of $45^{\circ} \mathrm{C}$ before storing the extract at $4{ }^{\circ} \mathrm{C}$ for further use (Lienou et al. 2015). The same procedure was followed for the methanol extraction using $80 \%$ methanol. The percentage yield of the extracts was calculated based on the formula used by Zhang et al. (2007) as follows:

$$
\text { Extract yield } \%=\frac{\text { weight of the dry extract }}{\text { weight of the original sample }} \times 100 \text {. }
$$

\section{Caenorhabditis elegans populations for bioassay}

The strains (Bristol N2 (wild type/ivermectin susceptible) and DA1316 (ivermectin resistant) were sourced from the Caenorhabditis elegans Genetic Center, USA. Nematode growth medium (NGM) (mixture of $3 \mathrm{~g} \mathrm{NaCl}, 17 \mathrm{~g}$ agar and $2.5 \mathrm{~g}$ of Bacto peptone in $1000 \mathrm{ml}$ of distilled water and $1 \mathrm{ml}$ of $1 \mathrm{M} \mathrm{CaCl}_{2}, 1 \mathrm{ml}$ of $5 \mathrm{mg} / \mathrm{ml}$ cholesterol, $1 \mathrm{ml}$ of $1 \mathrm{M} \mathrm{MgSO}_{4}$ and $25 \mathrm{ml}$ of $1 \mathrm{M} \mathrm{KPO}_{4}$ buffer, all autoclaved except cholesterol) seeded with a lawn of Escherichia coli OP50 was used to maintain the C. elegans as described by Brenner (1974).

The synchronized population of C. elegans strains used in this experiment was obtained by adding $6 \mathrm{ml}$ of distilled water to an old plate of the required strain and then agitated by hand shaking to stir eggs and gravid worms. The suspension containing eggs and gravid worms was transferred to $15 \mathrm{ml}$ centrifuge tube and centrifuged at $1500 \mathrm{rpm}$ for $1 \mathrm{~min}$. The clear supernatant was carefully discarded followed by the addition of $5 \mathrm{ml}$ of fresh alkaline bleaching solution (a mixture of $1 \mathrm{M} \mathrm{NaOH}$ and hypochlorite solution in the ratio of 1:2) to about $1 \mathrm{ml}$ of the pelleted mixture. The content was vigorously shaken with occasional vortexing and monitored under a microscope until appreciable dissolution of bacteria and gravid worms was observed. Eight millilitres of Minimal salts (M9) buffer (3 $\mathrm{g} \mathrm{KH}_{2} \mathrm{PO}_{4}, 6 \mathrm{~g} \mathrm{Na}_{2} \mathrm{HPO}_{2}, 5 \mathrm{~g} \mathrm{NaCl}$ and 
$1 \mathrm{M} \mathrm{MgSO}_{4}$ in $1 \mathrm{l}$ of distilled water) (Stiernagle 2006) was then added to end the bleaching process. The content was centrifuged at $1500 \mathrm{rpm}$, aspirated and re-suspended in M9 and the process of centrifuging was repeated until the bacteria and the dissolved worms were washed off. The pelleted eggs were re-suspended in $1 \mathrm{ml}$ of M9 buffer and transferred to NGM plate and incubated overnight at $20{ }^{\circ} \mathrm{C}$ in a shaker. The L1 larvae were observed the next day (Baugh 2013). The newly hatched L1 larvae were incubated on $E$. coli OP50-seeded NGM plate at $20^{\circ} \mathrm{C}$ for $40 \mathrm{~h}$ after which the L4 larvae were observed (Radman et al. 2013).

\section{Bioassay}

Synchronized populations of L4 larvae were used for the assay. Stock solutions of $2.0 \mathrm{mg} / \mathrm{ml}$ of G. senegalensis extracts were prepared by dissolving $200 \mathrm{mg}$ of the extracts in $5 \mathrm{ml}$ of $1 \%$ Tween 80 and $95 \mathrm{ml}$ of M9 buffer. These were diluted further with M9 to obtain the test concentrations (Table 1) for the assay. A $0.02 \mu \mathrm{g} / \mathrm{ml}$ of ivermectin was also prepared and the assay was carried out in a 24-well culture plate as described in Gagman et al. (2020). A suspension $(50 \mu \mathrm{l})$ containing about 100 L4 larvae of the $C$. elegans strain to be tested was added to each of the 24 wells. Exactly $1 \mathrm{ml}$ of each of the concentrations $(0.2,0.6,0.8,1.0$ and $2.0 \mathrm{mg} / \mathrm{ml})$ of the desired extract (methanol or aqueous) was added to the larvae in 3 wells. Larvae in another set of 3 wells were treated with $0.02 \mu \mathrm{g} / \mathrm{ml}$ of ivermectin and served as positive control while larvae in 3 wells treated with M9 solution only served as negative control. The setup was incubated at $20{ }^{\circ} \mathrm{C}$ until observation and counting of worms was carried out after 24 and $48 \mathrm{~h}$ using an inverted microscope. The larvae were considered immotile in the absence of tail, head or pharyngeal movement especially when pricked with nickel wire for at least $5 \mathrm{~s}$. Each experiment was repeated independently for 3 times. Percentage worm motility inhibition (WMI\%) within each well was calculated based on the formula (Tariq et al. 2009) below.

$\mathrm{WMI} \%=\frac{\text { number of worms in negative control well }- \text { number of mobile worms in treatment well }}{\text { number of worms in negative control well }} \times 100$.

Table 1 Motility of C. elegans L4 larvae after exposure to G. senegalensis extracts

\begin{tabular}{|c|c|c|c|c|c|}
\hline \multirow[t]{3}{*}{ Treatment } & \multirow[t]{3}{*}{ Concentration (mg/ml) } & \multicolumn{2}{|c|}{ C. elegans Bristol N2 } & \multicolumn{2}{|c|}{ C. elegans DA1316 } \\
\hline & & \multicolumn{4}{|c|}{$\%$ motility \pm SE } \\
\hline & & $24 \mathrm{~h}$ & $48 \mathrm{~h}$ & $24 \mathrm{~h}$ & $48 \mathrm{~h}$ \\
\hline \multirow[t]{6}{*}{ Aqueous extract } & 0.2 & $85.2 \pm 0.6^{a}$ & $72.2 \pm 0.6^{\mathrm{a}}$ & $88.8 \pm 0.6^{\mathrm{a}}$ & $73.2 \pm 0.6^{\mathrm{a}}$ \\
\hline & 0.4 & $82.9 \pm 0.9^{a}$ & $69.2 \pm 0.6^{b}$ & $84.2 \pm 0.6^{b}$ & $69.5 \pm 0.7^{b}$ \\
\hline & 0.6 & $78.9 \pm 0.7^{b}$ & $64.2 \pm 0.6^{c}$ & $80.2 \pm 0.6^{c}$ & $63.2 \pm 0.6^{c}$ \\
\hline & 0.8 & $72.9 \pm 0.6^{c}$ & $57.2 \pm 0.6^{d}$ & $76.6 \pm 0.6^{d}$ & $58.8 \pm 0.6^{d}$ \\
\hline & 1.0 & $67.6 \pm 0.7^{d}$ & $47.2 \pm 0.6^{e}$ & $68.9 \pm 0.7^{e}$ & $52.5 \pm 0.7^{e}$ \\
\hline & 2.0 & $58.9 \pm 0.7^{e}$ & $16.6 \pm 0.6^{f}$ & $63.9 \pm 0.7^{f}$ & $18.6 \pm 0.7^{f}$ \\
\hline Ivermectin $(0.02 \mu \mathrm{g} / \mathrm{ml})$ & & $38.6 \pm 1.0^{f}$ & $2.3 \pm 0.4^{9}$ & $98.5 \pm 0.2^{9}$ & $95.7 \pm 0.9^{9}$ \\
\hline \multirow[t]{2}{*}{ Negative control } & & $98.6 \pm 0.7^{9}$ & $97.4 \pm 0.7^{h}$ & $98.0 \pm 0.5^{9}$ & $96.1 \pm 0.4^{9}$ \\
\hline & & $p<0.001$ & $p<0.001$ & $p<0.001$ & $p<0.001$ \\
\hline \multirow[t]{6}{*}{ Methanol extract } & 0.2 & $77.9 \pm 0.6^{\mathrm{a}}$ & $63.2 \pm 0.6^{\mathrm{a}}$ & $80.2 \pm 0.6^{\mathrm{a}}$ & $67.5 \pm 0.6^{a}$ \\
\hline & 0.4 & $74.3 \pm 0.5^{\mathrm{a}}$ & $60.3 \pm 0.6^{\mathrm{a}}$ & $78.5 \pm 0.7^{\mathrm{a}}$ & $62.2 \pm 0.6^{b}$ \\
\hline & 0.6 & $69.6 \pm 0.7^{b}$ & $56.3 \pm 0.6^{b}$ & $74.2 \pm 0.6^{\mathrm{a}}$ & $59.5 \pm 0.7^{b}$ \\
\hline & 0.8 & $65.9 \pm 0.7^{c}$ & $52.3 \pm 0.6^{c}$ & $72.9 \pm 4.2^{\mathrm{a}}$ & $55.3 \pm 0.6^{c}$ \\
\hline & 1.0 & $57.3 \pm 0.6^{d}$ & $35.9 \pm 0.7^{d}$ & $61.2 \pm 0.6^{b}$ & $39.3 \pm 0.6^{d}$ \\
\hline & 2.0 & $51.8 \pm 0.6^{e}$ & $7.2 \pm 0.6^{e}$ & $54.2 \pm 0.6^{b}$ & $8.3 \pm 0.7^{e}$ \\
\hline Ivermectin $(0.02 \mu \mathrm{g} / \mathrm{ml})$ & & $36.5 \pm 0.9^{f}$ & $2.7 \pm 0.8^{f}$ & $98.0 \pm 0.2^{c}$ & $96.7 \pm 0.3^{f}$ \\
\hline \multirow[t]{2}{*}{ Negative control } & & $98.5 \pm 0.7^{9}$ & $97.3 \pm 0.4^{9}$ & $98.1 \pm 0.7^{c}$ & $97.4 \pm 0.7^{f}$ \\
\hline & & $p<0.001$ & $p<0.001$ & $p<0.001$ & $p<0.001$ \\
\hline
\end{tabular}

Motility values with the same alphabet in the same column for the same extract treatments are not significantly different at $p<0.05$ (Tukey's HSD test) 


\section{Data analysis}

The percentage means and standard error of the motility inhibition of the various concentrations of aqueous and methanol extracts of the plant against the larvae were calculated. Motility comparison between treatments was done using a one-way analysis of variance (ANOVA) for each treatment time for each extract for the different $C$. elegans strains. Post hoc test was performed using Tukey's honestly significant difference (HSD) test. Two-way ANOVA was conducted for the effect of treatment and treatment time on larval motility and their interaction for each extract on the nematode strains. Probit analysis was used in the computation of extract concentration required to cause $50 \%$ motility inhibition $\left(\mathrm{IC}_{50}\right)$. Statistical analysis was carried out using IBM SPSS ${ }^{\circledR}$ version 23 (IBM Corp. 2015).

\section{Results}

The percentage dry weight of 9.90 and $10.80 \%$ was recorded for aqueous and methanol extracts, respectively. Generally, motility inhibitory activity of the extracts against the larvae increased with increasing concentration of the extracts and the incubation time of the bioassay. Both the aqueous and methanol extracts exhibited good inhibitory activity against motility of the two C. elegans strains. The lowest performance for aqueous extract was recorded at $0.2 \mathrm{mg} / \mathrm{ml}$ after $24 \mathrm{~h}$ as the worm's motility was only reduced to $85.2 \%$ against C. elegans Bristol $\mathrm{N} 2$ and $88.8 \%$ against C. elegans DA1316 by the aqueous extract (Table 1). As concentration of the aqueous extract increased to $2.0 \mathrm{mg} / \mathrm{ml}$ at $24 \mathrm{~h}$, the worm's motility was further reduced to $58.9 \%$ against C. elegans Bristol N2 and $63.9 \%$ against C. elegans DA1316. The methanolic extract had a higher activity than the aqueous extract with a reduction in worm motility to $77.9 \%$ and $80.2 \%$ for C. elegans Bristol N2 and DA1316, respectively, at $0.2 \mathrm{mg} / \mathrm{ml}$ after $24 \mathrm{~h}$ and to 51.8 and $54.2 \%$, respectively, at $2 \mathrm{mg} / \mathrm{ml}$ after $24 \mathrm{~h}$ of methanolic extract exposure.

The highest efficacy of the extracts was observed at the highest concentration of $2.0 \mathrm{mg} / \mathrm{ml}$ after $48 \mathrm{~h}$ as aqueous extract reduced larval motility to $16.6 \%$ whereas methanol extract reduced the motility to $7.2 \%$ against C. elegans Bristol N2. On the other hand, aqueous extract reduced the motility of C elegans DA1316 to $18.6 \%$ while methanol extract reduced the motility to $8.3 \%$ (Table 1 ). The results indicated a significant difference $(p<0.001)$ between the efficacy exhibited by concentrations of the plant extracts, ivermectin and the negative control in both strains. The efficacy of ivermectin was higher and significantly different from that of the extracts and the negative control on C. elegans Bristol N2. However, efficacy of plant extracts was significantly higher than both the negative control and ivermectin throughout the various concentrations at $24 \mathrm{~h}$ as well as $48 \mathrm{~h}$ against C. elegans DA1316. Larval motility for the treatments was significantly different at $24(p<0.001)$ and $48 \mathrm{~h}(p<0.001)$ for both aqueous and methanol extracts for the two $C$ elegans strains. There was also a significant difference in motility under the different treatments $(p<0.001)$, treatment time $(p<0.001)$ and treatment-treatment time interaction $(p<0.001)$ for the aqueous and methanol extracts of G. senegalensis on $C$ elegans Bristol N2 strain. Similarly, larval motility was significantly different for the treatments $(p<0.001)$, treatment time $(p<0.001)$ and their interaction $(p<0.001)$ for the two extracts on $C$ elegans DA1316 strain.

Data in Table 2 indicated higher efficacy of methanol extract of G. senegalensis than aqueous extract and this was proven by the lower $\mathrm{IC}_{50}$ of $0.679 \mathrm{mg} / \mathrm{ml}$ for methanol extract compared to the $\mathrm{IC}_{50}$ of 0.947 exhibited by the aqueous extract against $C$. elegans Bristol N2. Similarly, methanol extract exhibited a lower $\mathrm{IC}_{50}$ of $0.766 \mathrm{mg} / \mathrm{ml}$ compared to the $\mathrm{IC}_{50}$ of $1.004 \mathrm{mg} / \mathrm{ml}$ recorded by the aqueous extract against C. elegans DA1316.

\section{Discussion}

Anthelmintic potential of G. senegalensis on larval motility of $C$. elegans was assessed in vitro as an alternative to commercial anthelmintics and in managing ivermectin-resistant parasitic nematodes. This study was done because despite the usage of $G$. senegalensis as a traditional anthelmintic in Nigeria (Akuodor et al. 2013; Ademola 2016), its activity against nematodes is unknown. This work is a corollary to Gagman et al. (2018) which evaluated the ability of $G$. senegalensis to inhibit the hatching of $C$. elegans eggs and the development of its larvae. Based on the motility inhibition thresholds (Powers et al. 1982), the aqueous extract $(2 \mathrm{mg} / \mathrm{ml}$ at $48 \mathrm{~h}$ of treatment) of G. senegalensis was moderately effective

Table $2 I_{50}$ of $G$. senegalensis extracts against C. elegans $L 4$ larvae after $48 \mathrm{~h}$ of exposure

\begin{tabular}{|c|c|c|c|c|c|c|}
\hline \multirow[t]{2}{*}{ Extract } & \multicolumn{3}{|c|}{ C. elegans Bristol N2 } & \multicolumn{3}{|c|}{ C. elegans DA1316 } \\
\hline & $\mathrm{IC} C_{50}(\mathrm{mg} / \mathrm{ml})$ & LB & UB & $\mathrm{IC} \mathrm{C}_{50}(\mathrm{mg} / \mathrm{ml})$ & LB & UB \\
\hline Aqueous & $0.947^{\mathrm{a}}$ & 0.879 & 1.021 & $1.004^{\mathrm{a}}$ & 0.931 & 1.083 \\
\hline Methanol & $0.679^{b}$ & 0.617 & 0.740 & $0.766^{b}$ & 0.707 & 0.827 \\
\hline
\end{tabular}

$\mathrm{IC}_{50}$, concentration that inhibits the motility of the larvae by $50 \%$; UB, upper boundary; $\mathrm{LB}$, lower boundary. $\mathrm{IC}_{50}$ values with different alphabets in the same column are significantly different based on their overlapping $95 \%$ confidence limits 
(80-90\% motility inhibition) against both strains of $C$. elegans while the methanol extract $(2 \mathrm{mg} / \mathrm{ml}$ at $48 \mathrm{~h}$ of treatment) was highly effective ( $>90 \%$ motility inhibition). The G. senegalensis extracts in this study generally exhibited greater inhibition activity compared to aqueous and methanol extracts of Cassia siamea from Nigeria assayed on these C. elegans strains (Gagman et al. 2020).

Plant constituents such as secondary metabolites contribute to the biological efficacy of plant extracts. Secondary metabolites like tannins, alkaloids and flavonoids among others have been detected in extracts of G. senegalensis (Akuodor et al. 2013; Besier et al. 2016; Gagman et al. 2018). According to Azas et al. (2002), an alkaloid from G. senegalensis demonstrated the strongest antiplasmodial activity among several plants tested. Tannins also adversely affect the physiology of nematodes thereby marring developmental processes and abilities in eggs and larvae and culminating in mortality (AlonsoDíaz et al. 2011; Williams et al. 2014; Debiage et al. 2016). Work by Athanasiadou et al. (2000) also indicated the anthelmintic effects of condensed tannins on Trichostrongylus colubriformis. The effects include a reduction in hatching of eggs and development of larvae as well as inducing mortality (Athanasiadou et al. 2000; Min and Hart 2003). Saponins also contribute to anthelmintic activity of extracts by enhancing cell membrane permeability leading to nematode mortality (Wang et al. 2010). Alkaloids, tannins, saponins and phenols have been identified in G. senegalensis extracts sourced from the study location (Gagman et al. 2018; Adebayo et al. 2019), hence, the efficacy of $G$. senegalensis could be attributed to the secondary metabolites in the extracts.

The inhibitory efficacy of methanol and aqueous extracts increased with increasing concentration and treatment time, similar to the finding of Iqbal et al. (2012) where it was reported that the ovicidal and larvicidal efficacy of aqueous and methanol extracts of Azadirachta indica was time and concentration dependent. Also, Tariq et al. (2009) reported that the anthelmintic potency of Artemisia absinthium against ovine nematodes increased with increasing time and concentration. Recently, Hassan et al. (2021) also observed a concentration-dependent in vitro activity of crude ethanolic extracts of Artemisia herba-alba, Allium sativa and Balanites aegyptiaca on Haemonchus contortus. The $\mathrm{IC}_{50}$ of the G. senegalensis extracts indicates varying inhibition abilities on the $C$. elegans strains. A significant difference was observed between the $\mathrm{IC}_{50}$ of the aqueous and methanol extracts of $G$. senegalensis against motility of L4 larvae of C. elegans Bristol N2 and DA1316 $(p<0.05)$. The $\mathrm{IC}_{50}$ value of the aqueous extract $(0.947 \mathrm{mg} / \mathrm{ml})$ was higher than that of the methanol extract $(0.679 \mathrm{mg} /$ $\mathrm{ml}$ ) against $C$. elegans Bristol N2. Similarly, the aqueous extract exhibited a higher $\mathrm{IC}_{50}$ value of $1.004 \mathrm{mg} / \mathrm{ml}$ compared to the methanol extract $\left(\mathrm{IC}_{50}=0.766 \mathrm{mg} / \mathrm{ml}\right.$ ) against $C$. elegans DA1316. This relates to the findings of Elandalousi et al. (2013) and Lone et al. (2013) regarding the differential activities of plant extracts obtained with different solvents. The low performance of the aqueous extract in relation to the methanol extract could be attributed to the low diversity of metabolites in the aqueous extract compared to methanol extract (Gagman et al. 2018). While saponins, tannins and phenols were present in both extracts, alkaloids, terpenoids, flavonoids and several others were only present in the methanol extract (Gagman et al. 2018). The high diversity of metabolites in the methanol extract could be due to the ability of methanol to extract diverse compounds compared to water, which only extracted polar compounds (Tiwari et al. 2011; Iloki-Assanga et al. 2015; Nguyen et al. 2015).

The difference in effectiveness of the extracts could also be due to the different concentrations of phenolic and tannic compounds in the extracts as reported by Badar et al. (2011). Gagman et al. (2018) recorded total phenolic and tannin contents of $326.37 \mathrm{GAE} / \mathrm{mg}$ and $2.78 \mathrm{TAE} / \mathrm{mg}$ for aqueous extract of G. senegalensis and 288.67 GAE/ $\mathrm{mg}$ and $3.85 \mathrm{TAE} / \mathrm{mg}$ for methanol extract, respectively. However, sometimes the difference in potency between aqueous and methanol extracts may not be due to the quantity of tannins and other phenolic compounds, but rather due to the enzyme polyphenol oxidase which is very active in aqueous extracts and causes phenol degradation rendering them inactive irrespective of their quantity. The enzyme is however inactive in methanol extracts, thereby not inhibiting the activity of polyphenols in the extracts and invariably anthelmintic activity (Tiwari et al. 2011).

The difference between the positive control (larvae treated with $0.02 \mu \mathrm{g} / \mathrm{ml}$ ivermectin) and treatments with the various extract concentrations for both methanolic and aqueous extracts against C. elegans DA1316, which is ivermectin resistant, was statistically significant. The aqueous and methanol extracts of G. senegalensis were effective against the motility of C. elegans DA1316, but the organism was resistant to $0.02 \mu \mathrm{g} / \mathrm{ml}$ ivermectin even after exposure for $48 \mathrm{~h}$. Susceptibility of C. elegans DA1316 to the extracts of G. senegalensis may be attributed to the fact that the extracts may exhibit different modes of action against the nematode compared to ivermectin. A similar assumption was made by Kumarasingha et al. (2014) who found that extracts from Picria felterrae induced a stress response in C. elegans wild type and stress reporter (GFP-tagged) strains in a manner different from those of doramectin and levamisole. Work by Ndjonka et al. (2014) and Piña-Vázquez et al. (2017) indicated that some plant extracts and their individual 
constituents were effective against various drug-resistant C. elegans strains, providing an alternative source of effective chemotherapeutic agents. Susceptibility of the ivermectin-resistant strain of C. elegans to the extracts of $G$. senegalensis in this study indicates the potential of using these extracts against drug-resistant nematodes and as a source of anthelmintic drugs against nematodes which are resistant to conventional anthelmintics. These extracts could be explored for application in diverse fields including pest and disease control (Dirar and Devkota 2021). For instance, in Adebayo et al. (2019), G. senegalensis was suggested as a potential source of chemotherapeutic agents against breast cancer due to its antioxidant and antiproliferative effects and constituent compounds.

\section{Conclusions}

In this study, the anthelmintic use of G. senegalensis as a dewormer for small ruminants in Nigerian was validated in vitro using methanol and aqueous extracts of the plant against the motility of L4 larvae of two $C$. elegans strains: Bristol N2 and DA1316. The efficacy of G. senegalensis on both strains indicates its utility as a natural source of anthelmintic compounds for controlling ivermectin-resistant parasitic nematodes. Further research is required to establish the active compound(s) responsible for the activity of the extracts. There is also the need to conduct other in vitro and in vivo tests using G. senegalensis extracts on ivermectin-resistant parasitic nematodes.

\section{Abbreviations \\ ANOVA: Analysis of variance; HSD: Honestly significant difference; $I_{50}: 50 \%$ Motility inhibition concentration; M9: Minimal salts; NGM: Nematode growth medium; WMI: Worm motility inhibition.}

\section{Acknowledgements}

The authors are grateful to Universiti Sains Malaysia for laboratory and instrumental support and the laboratory staff for technical aids in this project. The immense contribution of Dr. Sultant Ayesh Mohammed Saghir of the Pharmacology Department, School of Pharmaceutical Sciences, Universiti Sains Malaysia, is also acknowledged.

\section{Authors' contributions}

$\mathrm{HAG}, \mathrm{HA}$, NAIINH and SWA designed various aspects of the experiments. $\mathrm{HA}$ and NAIINH supervised the work. HAG conducted the experiments and wrote the first draft. HAG and SWA performed statistical analysis. All authors revised and approved the final article. All authors read and approved the final manuscript.

\section{Funding}

This research was funded by Universiti Sains Malaysia (Research University Grant: 1001/PBIOLOGI/811275). HAG was supported by an award from the Government of Bauchi State, Nigeria. The funding bodies had no role in the design of the study, collection, analysis and interpretation of data and writing the manuscript.

\section{Availability of data and materials}

The datasets used and/or analysed during the current study are included in this published article.

\section{Declarations}

Ethics approval and consent to participate

Not applicable.

\section{Consent for publication}

Not applicable.

\section{Competing interests}

The authors declare that they have no competing interests.

\section{Author details}

${ }^{1}$ School of Biological Sciences, Universiti Sains Malaysia, 11800 Gelugor, Penang, Malaysia. ${ }^{2}$ Department of Biological Sciences, Faculty of Science, Bauchi State University Gadau, 751 Itas Gadau, Nigeria. ${ }^{3}$ Entomology Division, Cocoa Research Institute of Ghana, New Tafo-Akim, Eastern Region, Ghana.

Received: 26 November 2021 Accepted: 19 December 2021

Published online: 04 January 2022

\section{References}

Adamu HM, Abayeh O, Agho M, Abdullahi A, Uba A, Dukku H, Wufem B (2005) An ethnobotanical survey of Bauchi State herbal plants and their antimicrobial activity. J Ethnopharmacol 99(1):1-4. https://doi.org/10.1016/j.jep. 2004.12.025

Adebayo IA, Gagman HA, Balogun WG, Adam MAA, Abas R, Hakeem KR, Him NAIIBN, Samian MRB, Arsad H (2019) Detarium microcarpum, Guiera senegalensis, and Cassia siamea induce apoptosis and cell cycle arrest and inhibit metastasis on MCF7 breast cancer cells. Evid Based Complement Alternat Med 2019:6104574. https://doi.org/10.1155/2019/6104574

Ademola IO (2016) The potential of Nigerian bioactive plants for controlling gastrointestinal nematode infection in livestock. Anim Health Res Rev 17(2):85-91. https://doi.org/10.1017/S1466252316000049

Akuodor GC, Essien AD, David-Oku E, Chilaka KC, Akpan JL, Ezeokpo B, Ezeonwumelu JOC (2013) Gastroprotective effect of the aqueous leaf extract of Guiera senegalensis in albino rats. Asian Pac J Trop Med 6(10):771-775. https://doi.org/10.1016/S1995-7645(13)60136-4

Alonso-Díaz MA, Torres-Acosta JFJ, Sandoval-Castro CA, Hoste H (2011) Comparing the sensitivity of two in vitro assays to evaluate the anthelmintic activity of tropical tannin rich plant extracts against Haemonchus contortus. Vet Parasitol 181(2-4):360-364. https://doi.org/10.1016/j.vetpar. 2011.03.052

Alshafei NK, Ahmed SM, Abdelfattah N (2016) Preliminary observations on the uses of Guiera senegalensis as a traditional medicinal plants in Western Kurdofan, Sudan. Int J Appl Pure Sci Agric 2(5):42-48

Arsenopoulos KV, Fthenakis GC, Katsarou El, Papadopoulos E (2021) Haemonchosis: a challenging parasitic infection of sheep and goats. Animals 11:363. https://doi.org/10.3390/ani11020363

Athanasiadou S, Kyriazakis I, Jackson F, Coop RL (2000) Consequences of long-term feeding with condensed tannin on sheep parasitized with Trichostrongylus colubriformis. Int J Parasitol 30(9):1025-1033. https://doi. org/10.1016/S0020-7519(00)00083-7

Azas N, Laurencin N, Delmas F, Di Giorgio C, Gasquet M, Laget M, Timon-David $P$ (2002) Synergistic in vitro antimalarial activity of plant extracts used as traditional herbal remedies in Mali. Parasitol Res 88(2):165-171. https:// doi.org/10.1007/s004360100454

Badar N, lqbal Z, Khan MN, Akhtar MS (2011) In vitro and in vivo anthelmintic activity of Acacia nilotica (L.) willd. ex delile bark and leaves. Pak Vet J 31(3):185-191

Baugh LR (2013) To grow or not to grow: nutritional control of development during Caenorhabditis elegans L1 arrest. Genetics 194(3):539-555. https:// doi.org/10.1534/genetics.113.150847

Besier RB, Kahn LP, Sargison ND, Van Wyk JA (2016) The pathophysiology, ecology, and epidemiology of Haemonchus contortus infection in small 
ruminants. Adv Parasitol 93:95-143. https://doi.org/10.1016/bs.apar.2016. 02.022

Brenner S (1974) The genetics of Caenorhabditis elegans. Genetics 77(1):71-94. https://doi.org/10.1093/genetics/77.1.71

Burns AR, Luciani GM, Musso G, Bagg R, Yeo M, Zhang Y, Rajendran L, Glavin J, Hunter R, Redman E, Stasiuk S, Schertzberg M, Angus McQuibban G, Caffrey CR, Cutler SR, Tyers M, Giaever G, Nislow C, Fraser AG, MacRae CA, Gilleard J, Roy PJ (2015) Caenorhabditis elegans is a useful model for anthelmintic discovery. Nat Commun 6:7485. https://doi.org/10.1038/ ncomms 8485

Debiage RR, Gonçalves FMF, Pereira AR, da Silva RMG, Yoshihara E, de Mello Peixoto ECT (2016) Anthelmintic potential of Psidium guajava in sheep. Planta Med 82(S 01):S1-S381. https://doi.org/10.1055/s-0036-1596981

Dirar Al, Devkota HP (2021) Ethnopharmacological uses, phytochemistry and pharmacological activities of Guiera senegalensis J.F. Gmel. (Combretaceae). J Ethnopharmacol 267:113433. https://doi.org/10.1016/j. jep.2020.113433

Elandalousi RB, Akkari H, B'chir F, Gharbi M, Mhadhbi M, Awadi S, Darghouth MA (2013) Thymus capitatus from Tunisian arid zone: chemical composition and in vitro anthelmintic effects on Haemonchus contortus. Vet Parasitol 197(1-2):374-378. https://doi.org/10.1016/j.vetpar.2013. 05.016

Gagman HA, Irwan NA, Ahmad HB (2018) In vitro study of the anthelmintic activity of aqueous and methanol extract of Guiera senegalensis against egg hatch and larval developmental of Caenorhabditis elegans. Bayero J Pure Appl Sci 11(2):274-278. https://doi.org/10.4314/bajopas.v11i2.38

Gagman HA, Him NAIIN, Ahmad H, Sulaiman SF, Zakaria R, Termizi FHM (2020) In vitro efficacy of aqueous and methanol extract of Cassia siamea against the motility of Caenorhabditis elegans. Trop Life Sci Res 31(3):145-159. https://doi.org/10.21315/tlsr2020.31.3.10

Hahnel SR, Roberts WM, Heisler I, Kulke D, Weeks JC (2021) Comparison of electrophysiological and motility assays to study anthelmintic effects in Caenorhabditis elegans. Int J Parasitol Drugs Drug Resist 16:174-187. https://doi.org/10.1016/j.ijpddr.2021.05.005

Hassan NMF, Zaghawa AA, Abu-Elezz NMT, Nayel MA, Salama AA (2021) Efficacy of some Egyptian native plant extracts against Haemonchus contortus in vitro and in experimentally infected sheep along with the associated haematological and biochemical alterations. Bull Natl Res Cent 45:180. https://doi.org/10.1186/s42269-021-00636-5

Herrera-Manzanilla FA, Ojeda-Robertos NF, González-Garduño R, CámaraSarmiento R, Torres-Acosta JFJ (2017) Gastrointestinal nematode populations with multiple anthelmintic resistance in sheep farms from the hot humid tropics of Mexico. Vet Parasitol Reg Stud Rep 9:29-33. https://doi.org/10.1016/j.vprsr.2017.04.007

Holden-Dye L, Walker RJ (2014) Anthelmintic drugs and nematocides: studies in Caenorhabditis elegans. In: The C. elegans Research Community (ed) WormBook. WormBook, Southampton. https://doi.org/10.1895/ wormbook.1.143.2

Hoste $H$ (2001) Adaptive physiological processes in the host during gastrointestinal parasitism. Int J Parasitol 31(3):231-244. https://doi.org/10. 1016/S0020-7519(00)00167-3

IBM Corp. (2015) IBM SPSS statistics for Windows, Version 23.0. IBM Corp., Armonk

Iloki-Assanga SB, Lewis-Luján LM, Lara-Espinoza CL, Gil-Salido AA, Fernandez-Angulo D, Rubio-Pino JL, Haines DD (2015) Solvent effects on phytochemical constituent profiles and antioxidant activities, using four different extraction formulations for analysis of Bucida buceras $\mathrm{L}$. and Phoradendron californicum. BMC Res Notes 8:396. https://doi.org/ 10.1186/s13104-015-1388-1

Iqbal Z, Babar W, Din Sindhu Z, Abbas RZ, Sajid MS (2012) Evaluation of anthelmintic activity of different fractions of Azadirachta indica A. Juss Seed Extract. Pak Vet J 32(4):579-583

Jackson F, Varady M, Bartley DJ (2012) Managing anthelmintic resistance in goats_can we learn lessons from sheep? Small Rumin Res 103(1):3-9. https://doi.org/10.1016/j.smallrumres.2011.10.012

Katiki LM, Ferreira JFS, Zajac AM, Masler C, Lindsay DS, Chagas ACS, Amarante AFT (2011) Caenorhabditis elegans as a model to screen plant extracts and compounds as natural anthelmintics for veterinary use. Vet Parasitol 182(2-4):264-268. https://doi.org/10.1016/j.vetpar.2011. 05.020
Keiser J (2015) Is Caenorhabditis elegans the magic bullet for anthelminthic drug discovery? Trends Parasitol 31(10):455-456. https://doi.org/10. 1016/j.pt.2015.08.004

Kumarasingha R, Palombo EA, Bhave M, Yeo TC, Lim DSL, Tu CL, Shaw JM, Boag PR (2014) Enhancing a search for traditional medicinal plants with anthelmintic action by using wild type and stress reporter Caenorhabditis elegans strains as screening tools. Int J Parasitol 44(5):291-298. https://doi.org/10.1016/j.ijpara.2014.01.008

Lienou LL, Telefo PB, Njimou JR, Nangue C, Bayala BR, Goka SC, Biapa P, Yemele MD, Donfack NJ, Mbemya JT, Tagne SR, Rodrigues APR (2015) Effect of the aqueous extract of Senecio biafrae (Oliv. \& Hiern) J. Moore on some fertility parameters in immature female rat. J Ethnopharmacol 161:156-162. https://doi.org/10.1016/j.jep.2014.12.014

Lone BA, Bandh SA, Chishti MZ, Bhat FA, Tak H, Nisa H (2013) The anthelmintic and antimicrobial activity of methanolic and aqueous extracts of Euphorbia helioscopia L. Trop Anim Health Prod 45(3):743-749. https:// doi.org/10.1007/s11250-012-0283-1

Mazhangara IR, Sanhokwe M, Chivandi E, Mupangwa JF, Lorenzo JM, Muchenje V (2020) Plants for controlling parasites in goats. In: McGaw L, Abdalla M (eds) Ethnoveterinary medicine. Springer, Cham. https:// doi.org/10.1007/978-3-030-32270-0_5

Min BR, Hart SP (2003) Tannins for suppression of internal parasites. J Anim Sci 81(14 Suppl 2):E102-E109

Mphahlele M, Tsotetsi-Khambule AM, Moerane R, Komape DM, Thekisoe OMM (2021) Anthelmintic resistance and prevalence of gastrointestinal nematodes infecting sheep in Limpopo Province, South Africa. Vet World 14(2):302-313. https://doi.org/10.14202/vetworld.2021.302-313

Ndjonka D, Abladam ED, Djafsia B, Ajonina-Ekoti I, Achukwi MD, Liebau E (2014) Anthelmintic activity of phenolic acids from the axlewood tree Anogeissus leiocarpus on the filarial nematode Onchocerca ochengi and drug-resistant strains of the free-living nematode Caenorhabditis elegans. J Helminthol 88(4):481-488. https://doi.org/10.1017/S0022 $149 \times 1300045 X$

Nguyen VT, Bowyer MC, Vuong QV, Altena IAV, Scarlett CJ (2015) Phytochemicals and antioxidant capacity of Xao tam phan (Paramignya trimera) root as affected by various solvents and extraction methods. Ind Crops Prod 67:192-200. https://doi.org/10.1016/j.indcrop.2015.01.051

Piña-Vázquez DM, Mayoral-Peña Z, Gómez-Sánchez M, Salazar-Olivo LA, Arellano-Carbajal F (2017) Anthelmintic effect of Psidium guajava and Tagetes erecta on wild-type and levamisole-resistant Caenorhabditis elegans strains. J Ethnopharmacol 202:92-96. https://doi.org/10.1016/j. jep.2017.03.004

Ploeger HW, Everts RR (2018) Alarming levels of anthelmintic resistance against gastrointestinal nematodes in sheep in the Netherlands. Vet Parasitol 262:11-15. https://doi.org/10.1016/j.vetpar.2018.09.007

Powers KG, Wood IB, Eckert J, Gibson T, Smith HJ (1982) World Associations of the Advancement of Veterinary Parasitology (W.A.A.V.P.) guidelines for evaluating the efficacy of anthelmintics in ruminants (bovine and ovine). Vet Parasitol 10(4):265-284. https://doi.org/10.1016/03044017(82)90078-4

Radman I, Greiss S, Chin JW (2013) Efficient and rapid C. elegans transgenesis by bombardment and hygromycin B selection. PLOS ONE 8(10):e76019. https://doi.org/10.1371/journal.pone.0076019

Singh R, Bal MS, Singla LD, Kaur P (2017) Detection of anthelmintic resistance in sheep and goat against fenbendazole by faecal egg count reduction test. J Parasit Dis 41:463-466. https://doi.org/10.1007/ s12639-016-0828-8

Stiernagle T (2006) Maintenance of C. elegans. In: The C. elegans Research Community (ed) WormBook. WormBook, Southampton. https://doi. org/10.1895/wormbook.1.101.1

Taki AC, Byrne JJ, Boag PR, Jabbar A, Gasser RB (2021) Practical highthroughput method to screen compounds for anthelmintic activity against Caenorhabditis elegans. Molecules 26:4156. https://doi.org/10 3390/molecules26144156

Tariq KA, Chishti MZ, Ahmad F, Shawl AS (2009) Anthelmintic activity of extracts of Artemisia absinthium against ovine nematodes. Vet Parasitol 160(1-2):83-88. https://doi.org/10.1016/j.vetpar.2008.10.084

Tiwari P, Kumar B, Kaur M, Kaur G, Kaur H (2011) Phytochemical screening and extraction: a review. Int Pharma Sci 1(1):98-106 
Wang G-X, Han J, Zhao L-W, Jiang D-X, Liu Y-T, Liu X-L (2010) Anthelmintic activity of steroidal saponins from Paris polyphylla. Phytomedicine 17(14):1102-1105. https://doi.org/10.1016/j.phymed.2010.04.012

Williams AR, Fryganas C, Ramsay A, Mueller-Harvey I, Thamsborg SM (2014) Direct anthelmintic effects of condensed tannins from diverse plant sources against Ascaris suum. PLoS ONE 9(5):e97053. https://doi.org/10. 1371/journal.pone.0097053

Yadav P, Singh R (2011) A review of anthelmintic drugs and their future scope. Int J Pharm Pharm Sci 3(3):17-21

Zajac AM, Garza J (2020) Biology, epidemiology, and control of gastrointestinal nematodes of small ruminants. Vet Clin Food Anim 36(1):73-87. https://doi.org/10.1016/j.cvfa.2019.12.005

Zhang S, Bi H-M, Liu C-J (2007) Extraction of bio-active components from Rhodiola sachalinensis under ultrahigh hydrostatic pressure. Sep Purif Technol 57(2):277-282. https://doi.org/10.1016/j.seppur.2007.04.022

\section{Publisher's Note}

Springer Nature remains neutral with regard to jurisdictional claims in published maps and institutional affiliations.

\section{Submit your manuscript to a SpringerOpen ${ }^{\circ}$ journal and benefit from:}

- Convenient online submission

- Rigorous peer review

- Open access: articles freely available online

- High visibility within the field

- Retaining the copyright to your article

Submit your next manuscript at $\boldsymbol{\nabla}$ springeropen.com 